\title{
Reconstruction of vocational high school physics instructional materials
}

\author{
Ira Herli Khoeriah ${ }^{a}$, Ade Gafar Abdullah ${ }^{\text {b* }}$, Budi Mulyanti ${ }^{\text {c }}$ \\ Technology and Vocational Education Study Program, Graduate School of Universitas Pendidikan Indonesia. \\ Jalan Dr. Setiabudhi 207 Bandung 40154 Indonesia \\ a iraherlikhoeriah@upi.edu., b ade_gaffar@upi.edu, ${ }^{\text {c }}$ bmulyanti@upi.edu \\ * Corresponding Author.
}

Received: 19 July 2020; Revised: 4 August 2020; Accepted: 12 August 2020

\begin{abstract}
Instructional materials for static electricity and dynamic electricity for Physics subjects in Vocational High Schools are not in accordance with the scope of the material contained in the Electronics Department: (1) The purpose of this study is to provide an overview of the teaching materials of static electricity and dynamic electricity in Physics in the Electronics Department; (2) Qualitative Content Analysis Method was used to explore the contents of seven book titles with different publishers and is strengthened through inter-views with Physics teachers in the Department of Electronics. In the process of analyzing the content of the contents of this textbook used Atlas.ti computer software; (3) The findings show that the content in the Vocational High School Physics books pub-lished by several publishers does not yet have specific conformity with the Department of Electronics; (4) conclusion. There are code relating to the content content, researchers only specify it into 39 code titles in the VHS Physics Textbook. from qualitative analysis. The level of compatibility of the content of the material with the 2013 Revised Curriculum was $42.86 \%$, the availability of pictures was $75 \%$, examples of questions from the equations of each series were $85.71 \%$, the suitability of the practicum with the Electrical Clump was $14.29 \%$. content conformity with the Revised 2013 Curriculum and electro majors has a slightly low percentage of $42.86 \%$. So in this study, the authors reconstruct VHS Physics teaching materials for the Electrical Department and also make VHS Physics teaching materials for the Electrical Clump.
\end{abstract}

Keywords: qualitative content analysis; teaching material; vocational physics

How to Cite: Khoeriah, I. H., Abdullah, A. G., \& Mulyanti, B. (2020). Reconstruction of physics vocational high school physics teaching materials. Momentum: Physics Education Journal, 4(2), 85-93. https://doi.org/10.21067/mpej.v4i2.4572

\section{Introduction}

Recently, PISA (Program for International Student Assessment) has reported that the literacy skills in reading, Mathematics and Science of students up to the age of 15 in Indonesia was still low. The results was influenced by the learning environment, instructional materials and learning disparities implemented by schools and did not meet the PISA demands (Hayat \& Yusuf, 2010 ; Kurnia et al., 2014). Instructional material plays a role to assist teachers in carrying out teaching and learning activities, both written and spoken material (Menteri Pendidikan Nasional Republik Indonesia, 2008). Instructional materials are arranged systematically that allow students to learn independently to acquire knowledge or competencies during the learning process (Levrini et al., 2014). Also, in accordance with its function, instructional materials facilitate teachers to teach the most appropriate content to students in accordance with predetermined learning goals (Fatima et al., 2015).

As one of the factors influencing students' literacy abilities and the quality of teaching and learning (Attri, 2012), the quality of instructional materials needs to be improved. The quality of instructional materials is determined by the ability and skills of teachers to analyze content that 
generates from various textbooks (Sorge et al., 2019). Thus, the material presented becomes more concise and easier to be understood by students (Pasaribu, 2017), which in turn can motivate students to actively participate in the learning process (Sekarwinahyu \& Rahayu, 2009).

A variety of instructional materials have been widely used in the learning process in Indonesia including modules, textbooks, digital books and other forms (Aji et al., 2017; Dewi, 2016). But in the reality, most teachers are more focused on textbooks as the main learning source (Niswa, 2013; Anisah \& Azizah, 2017). From the results of Wilsa's study (2019), it was found that student achievement using textbooks was lower compared to students who used interactive multimedia or internet. By using textbooks, students cannot develop the knowledge wider because it is only focused on one source of information (Wilsa, 2019). Several attempts were made to improve student achievement, one of the efforts was by increasing teacher skills in selecting proper text books based on profiles, content and conformity to the curriculum (Waloyo \& Arrasyid, 2019).

Vocational High School (VHS) is a secondary school level that prepares students to be ready for work. This is mentioned in Presidential Instruction No. 9 of 2016 on Revitalization of Vocational Schools, which represents 70 per cent of the practice and 30 per cent of the theory (Presiden Republik Indonesia, 2016). Subjects are concentrated in three groups: Adaptive Learning, Normative Learning and Productive Learning. Adaptive Learning and Normative Learning are non-vocational lessons given to students in support of productive capacity. While productive subjects are vocational training which are necessary skills given to students in accordance with the chosen program of expertise. Physics subjects are included in the group $\mathrm{C} 1$ of the productive subject.

Various approaches to learning Physics at vocational schools place more emphasis on increasing student creativity and critical thinking skills (Lisdianto et al., 2015). In addition, an introduction to learning that places more emphasis on material and interaction is provided for students to better understand Physics (Seung et al., 2012). Throughout this direction, the Physics content to be taught is analyzed in detail in order to achieve the main objective of learning, which include managing student thinking skills and building students' knowledge constructs based on information obtained (Saepuzaman \& Karim, 2016). Physics textbooks used by vocational school teachers as one of the references for the preparation of instructional materials must satisfy the level of readability of the material, the ease or difficulty of presenting the material and the attractiveness of vocational physics textbooks by providing pictures or illustrations that could really help in understanding the material (Kusuma, 2018).

The vocational schools in Indonesia comprise several areas of expertise, e.g. Technology and Engineering, Technology and Information, Energy and Mining, Information and Communication Technology, Health and Social Work, Agribusiness and Agrotechnology, Maritime, Business and Management, Tourism, Arts and Creative Industries. (Menteri Pendidikan dan Kebudayaan Republik Indonesia, 2018). Revised at the Vocational School, the Electrical Engineering Expertise Program and the Electronic Engineering Expertise Program have the same basic competencies, thus it is referred to as the Electrical Clusters (Mulyanti et al., 2020).

The field of Technology and Engineering comprises of Building Engineering, Plumbing and Sanitation Engineering, Surveying and Mapping Engineering, Electricity Engineering, Electronic Engineering, Pending and Air Conditioning Engineering, Mechanical Engineering, Automotive Engineering, Aircraft Technology, Shipping Engineering, Textile Technology, Graphic Engineering, Mining Geology, Industrial Engineering. Based on the 2013 Syllabus of Curriculum Physics.

The content of material in Physics textbooks published by several publishers is generally irrelevant to the curriculum of the Electronic program of Vocational School; most of them still use the curriculum before the 2013 Revised Curriculum (Fajriatin, 2015; Hartono et al., 2013)(Hartono et al., 2013). The Physics textbook for Vocational Schools from the Indonesian Ministry of Education was published on August 17, 2008. The textbook was not in accordance with the 2013 Revised Curriculum (Endarko et al., 2008). The content contained in a book must be derived from the Basic Competencies contained in the applicable curriculum, thus the book can be understood directly by all students (Kurniasih \& Sani, 2014). Physics textbooks for Vocational Schools from a number of publishers, even though they have used the 2013 Revised Curriculum, the scope of the material contained therein are 
still based on the field of expertise not a group of expertise programs. Thus, there are theoretical and practical materials that are less relevant to the Electrical Engineering expertise.

So far, the reconstruction of Physics textbooks has been carried out, especially for junior and senior high schools (Ding et al., 2011; Fitriyah, 2017). However, up to now, there is no Physics textbook reconstruction available for vocational high school level, especially for the Electrical Engineering. Therefore, this study aims to reconstruct the Electronical Vocational School Physics textbook. The process of reconstructing the textbook is carried out by a qualitative content analysis method with a coding system of each content analyzed (O'Donoghue et al., 2011; Graneheim \& Lundman, 2004; Bengtsson, 2016; Brown \& Vodopyanova, 2017; Clerici et al., 2013), using Atlas.ti software. The instrument was adapted to the learning model which contains sequential teaching descriptions and content of instructional materials by focusing on the validity of the content and also the students' metacognition (Brovelli et al., 2013; Taasoobshirazi \& Farley, 2013). In order to obtain a deep reconstruction of Physics teaching materials, this study is only limited to the Basic Competencies for Static Electricity and Dynamic Electricity.

\section{Method}

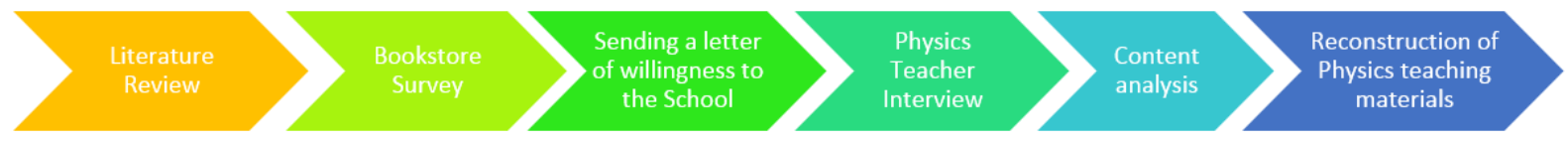

Figure 1. Research Design

The research design in reconstructing Physics teaching materials related to static electricity and dynamic electricity material in the electronics department is depicted in Figure 1 (Boman et al., 2017). Figure 1 shows the research design of teaching material reconstruction which consists of 6 stages. In the first stage, the researcher conducted a literature review that identified national and international journals related to the process of analyzing the content of Physics instructional materials in the middle school level. Content analysis was used as a research method. It employed Atlas.ti software to analyze each content studied. In the second stage, which was collecting data by conducting a survey in the bookstore directly from April to June 2019, the researchers only looked for vocational high school Physics textbooks in the field of technology and engineering expertise and in accordance with the revised 2013 Curriculum. This is because vocational majors in Indonesia consist of ten fields of expertise, including electronics engineering expertise in the fields of technology and engineering. The curriculum that applies in the 2019/2020 school year is the revised 2013 Curriculum. Based on the survey results in the bookstore, the researchers obtained seven vocational Physics textbooks with different publishers. The process of analyzing the content of Physics instructional materials from Vocational Physics textbooks circulating in bookstores and reinforced by the perception of Physics subject teachers who teach in the Electronics department. Instructional material or content that is reconstructed is only about static and dynamic electricity. In the third stage, which include the distribution of invitation letters to become informants sent to public vocational high schools in Indonesia $(n=5)$ from July to September 2019. School participation is focused on public schools that have electronics majors, this is needed to obtain relevant data with static electricity and dynamic electricity instructional materials at the Vocational Physics course through interviews with Physics teachers. The interview process is carried out directly by the researchers. The researchers submitted questions about 15 question content with three repetitions of interview sessions to obtain consistent answers to the questions asked. The results of the interview with the teacher were analyzed to obtain input related to the textbook used to serve as teaching material, the depth and suitability of static electricity, and dynamic electricity material that might be taken from several titles of the book to be reconstructed.

Content analysis was used to analyze content from textbooks using Atlas.ti computer software. Through this software the code was obtained from computerized content analysis (Evers \& Silver, 2014). The content analysis was systematically defined, a technique that can be replicated to com- 
press many words of text into fewer categories of content based on explicit coding rules. The reconstruction design of this instructional material was developed through the stages of orientation, elicitation, restructuring, application, and review (Karim et al., 2016). In the orientation phase, schools are chosen based on schools that have electronics majors. After deciding on the school, the informant, namely the Physics teacher in each school, determined: how many numbers of Physics textbooks are used as instructional materials, is there any basic electrical circuit competence in the vocational high school curriculum, how much is the suitability of electrical circuits in the electronics department, how the level of complexity of the book used, the title of the book which is the level of content compatibility is better with the electronics department. In the elicitation and restructuring step, the strengthening and review of the depth and suitability of the instructional materials for the electrical circuits of the book were focused. During the application step, it aimed at finding a formula to reconstruct electric circuit instructional materials starting from the basic material to the core material that is adjusted to the electronics department. In the last stage, which is a review, this stage reviews the results that have been obtained and formulated as a result of the reconstruction of electric circuit teaching materials for Vocational Physics courses.

\section{Results and Discussion}

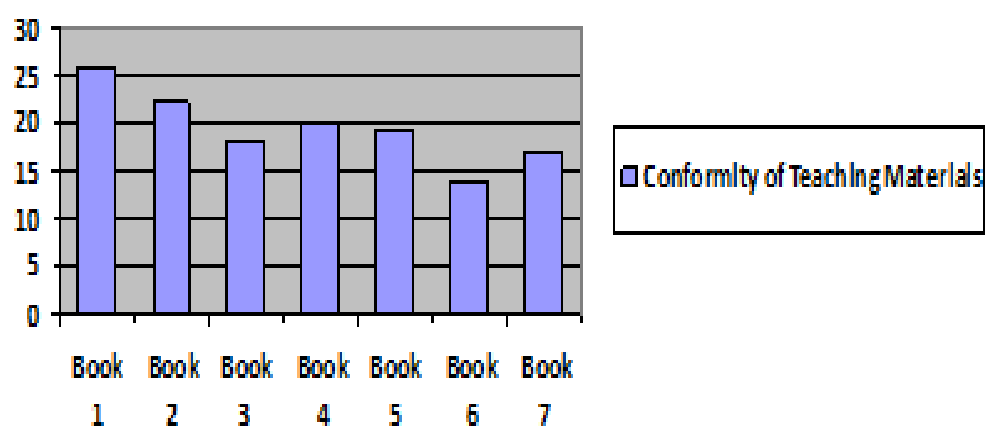

Figure 2. Conformity rating content of static electrical and electrical materials Dynamics

Figure 2 shows the suitability rating of static electricity and dynamic electricity instructional materials based on the results of content analysis. Based on Figure 2. In book 3, the 2013 Physics curriculum student book was the first printed book in 2019. The contents of the material in book 1 were quite complete, according to basic competencies in the 2013 curriculum. The content of the material only discusses the core of the learning objectives accompanied by a concept map, thus the material was quite concise and coherent according to the concept map contained in book 3 . Book 3 presents examples in accordance with the daily life contexts accompanied by pictures, thus students have sufficient initial insight to learn the material. However, the 3rd book does not explain the picture in detail. During the discussion, there was no color-coded table and an explanation of the procedures for reading components manually or using a measuring instrument. It does not explain in detail how to solve the problem from the law Kirchoff. From the Book 5, the Physics textbook based on curriculum was printed in August 2014. The contents of the material in book 5 are very complete, according to basic competencies in the 2013 Curriculum. Another advantage is that it presents examples in accordance with the daily life contexts accompanied by pictures, hence students have sufficient initial insight to learn the material. However, in the 5th book, the AC current is discussed in the next chapter. Thus, when students learn about the application of dynamic electricity capacitors, students cannot learn it completely. The color-coded tables and explanations on how to read components manually or using a measuring instrument are not available, even though this is the fundamental for students majoring in electronics to find out the value of these components. When the student participant cannot determine the value and foot of the component, it is most likely that the circuit will not function properly. The book 6 is in accordance with the 2013 Physics curriculum student book and was printed in June 2017. The contents of material in book 6 are very short, but it 
is still in accordance with basic competencies in the 2013 Curriculum. The examples of questions in the textbook are very complete. In addition, there were discussions on the National Exam from 1998 to 2016. There is no color-coded table and an explanation of the procedures for reading components manually or using measuring instruments. The book 7 is a Physics student book published by the Indonesian Ministry of Education printed in 2008. However, it still referred to the 2006 KTSP curriculum. The discussion of static and dynamic electricity is divided into two different chapters thus each static electricity material described was quite complete. Unfortunately, there is no color-coded table and an explanation of the procedures for reading components manually or using a measuring instrument. It does not explain in detail how to solve the problem from the law Kirchoff. Based on the description of the seven books analyzed, it can be concluded that there are only 3 Physics books that have been adapted to the revised 2013 Curriculum. While the books published by the Indonesian Ministry of Education are still based on the KTSP curriculum. This has become one of the difficulties for teachers to provide materials that are appropriate to the electronics department using the revised 2013 Curriculum. Thus, the reconstruc-tion of vocational school physics majoring in electronics in accordance with the Revised 2013 Curriculum is needed, especially regarding static electricity and dynamic electricity.

Based on the analysis using the Atlas.ti software, it obtained 175 quotations with 175 identified codes. Furthermore, the contents became 39 Title codes in the analysis of the suitability of the contents of the material in the Vocational Physics textbook, five Other code titles are Introduction, Core Competencies and Basic Competencies, Indicators, Learning Objectives and Application of Material Content in everyday life Excerpt function to show the relationship Title code contained in the contents of one textbook with other textbooks. The Figure 3 is an example of the results of content analysis of the content of the vocational high school Physics Textbook using Atlas.ti software.

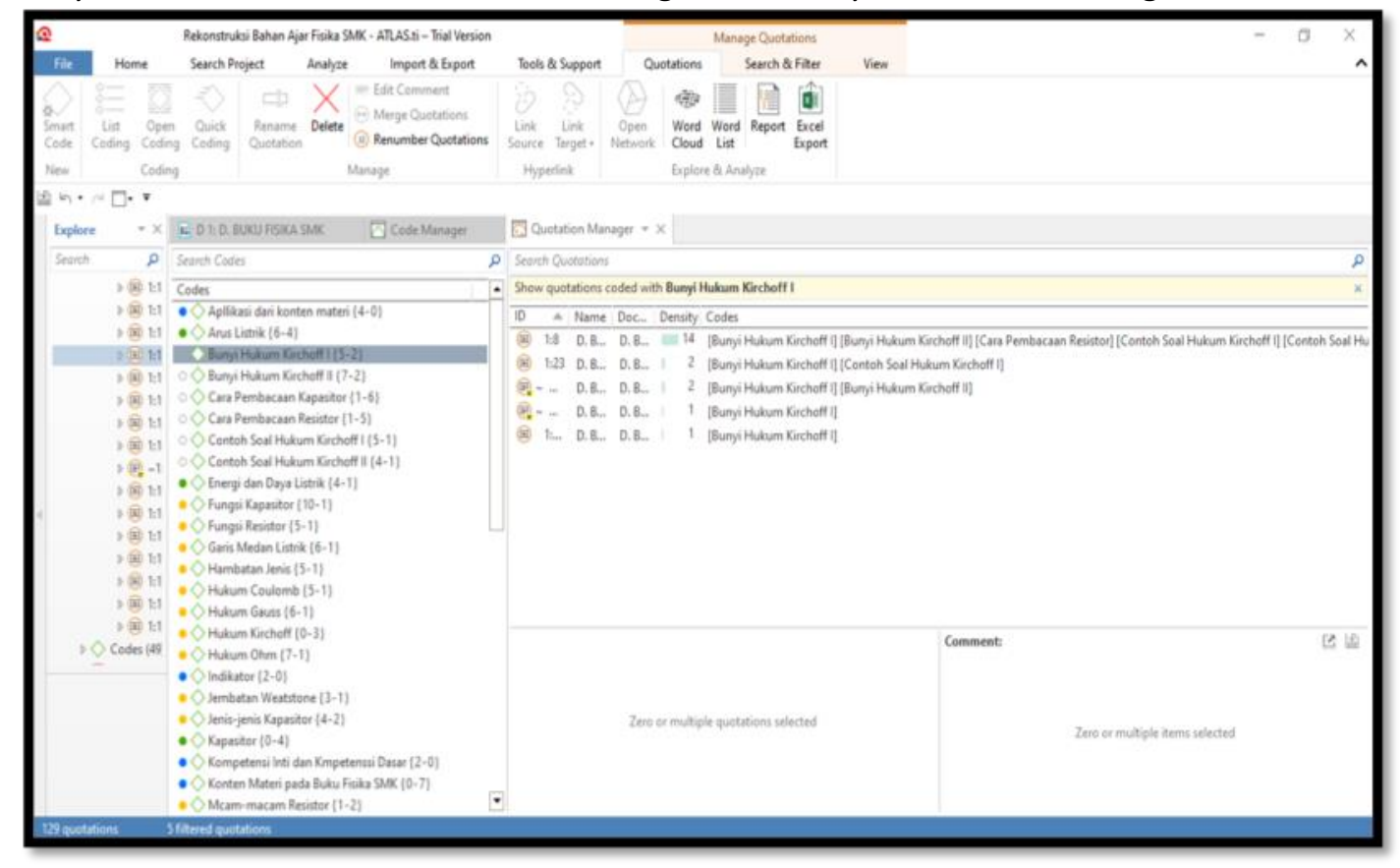

Figure 3. Results of the analysis of the sound of Kirchoff I Law Textbooks in VHS Physics using the Atlas.ti software

The following figure is a chart of the final results of analyzing the content of the contents of the vocational high school Physics textbook using the Atlas.ti device as a basis for reconstructing the vocational high school Physics teaching materials in the Electronics Departement. Figure 4 is a chart of the results of the analysis of the content of vocational high school Physics teaching materials in the electrical department using Atlas.ti. The chart plays a role as the basis for the researchers to compose vocational high school Physics instructional materials that have been reconstructed with the Revised 2013 Curriculum and in accordance with the electrical department. 
Momentum: Physics Education Journal, 4 (2), 2020, 90

Ira Herli Khoeriah, Ade Gafar Abdullah, Budi Mulyanti

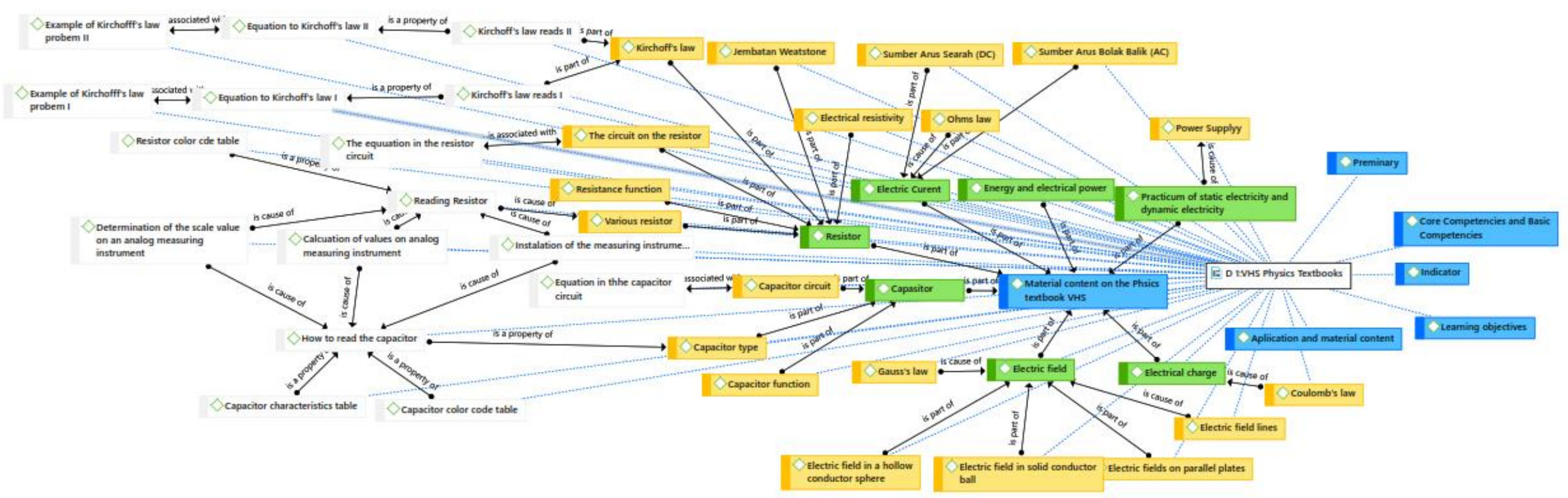

Figure 4. Chart the relationship between code one with other codes 


\section{Momentum: Physics Education Journal, 4 (2), 2020, 91}

Ira Herli Khoeriah, Ade Gafar Abdullah, Budi Mulyanti

\section{Conclusion}

The results using Atlas.ti software obtained 175 quotations and 175 codes of all content analyzed. Specifically, the codes were related to the content content. The researchers only specify it into 39 code titles in the vocational high school Physics Textbook. According to the qualitative analysis, the level of compatibility of the content of the material with the 2013 Revised Curriculum was $42.86 \%$, the availability of pictures was $75 \%$, the examples of questions from the equations of each series were $85.71 \%$, the suitability of the practicum was $14.29 \%$. The content conformity with the Revised 2013 Curriculum and electro majors has a slightly low percentage of $42.86 \%$. Thus, in this study, the authors reconstructed vocational high school Physics instructional materials for the Electrical Department and also compile vocational high school Physics instructional materials for the Electrical engineering.

\section{Acknowledgment}

The authors would like to send their greatest gratitude to Physics teachers of vocational high school in West Java Province who has been involved in research on the reconstruction of Physics textbooks in the Electrical Cluster, especially for Physics teachers at SMKN 1 Majalaya, SMKN 7 Baleendah, SMKN 4 Bandung, SMKN 1 Cikarang Selatan and SMKN 1 Sumedang.

\section{References}

Aji, S., Hudha, M. N., \& Rismawati, A. (2017). Pengembangan modul pembelajaran fisika berbasis problem based learning untuk meningkatkan kemampuan pemecahan masalah fisika. SEJ (Science Education Journal), 1(1), 36. https://doi.org/10.21070/sej.v1i1.830

Anisah, A., \& Azizah, E. N. (2017). Pengaruh penggunaan buku teks pelajaran dan internet sebagai sumber belajar terhadap hasil belajar siswa pada pembelajaran IPS. Jurnal Logika, 18(3), 1-18. http://jurnal.unswagati.ac.id/index.php/logika/article/view/215

Attri, A. K. (2012). Distance education: Problems and solutions. International Journal of Behavioral Social and Movement Sciences, 1(4), 42-58. http://ijobsms.in/v1s4p7.html

Bengtsson, M. (2016). How to plan and perform a qualitative study using content analysis. NursingPlus Open, 2, 8-14. https://doi.org/10.1016/j.npls.2016.01.001

Boman, J., Currie, G., MacDonald, R., Miller-Young, J., Yeo, M., \& Zettel, S. (2017). Overview of decoding across the disciplines. New Directions for Teaching and Learning, 2017(150), 13-18. https://doi.org/10.1002/tl.20234

Brovelli, D., Bölsterli, K., Rehm, M., \& Wilhelm, M. (2013). Erfassen professioneller kompetenzen für den naturwissenschaftlichen unterricht: Ein vignettentest mit authentisch komplexen unterrichtssituationen und offenem antwortformat. Unterrichtswissenschaft, 41(4), 306-329.

Brown, T. J., \& Vodopyanova, N. (2018). Is what you see what you get? A content analysis of the indicative nature of self-regulated comic book covers and their content. Journal of Graphic Novels and Comics, 9(2), 137-156. https://doi.org/10.1080/21504857.2017.1307238

Clerici, R., Gola, G., \& Cisco, E. (2013). Quali-quant analysis of the statistical content in Italian primary school general books. International Journal of Multiple Research Approaches, 7(1), 96-109. https://doi.org/10.5172/mra.2013.7.1.96

Dewi, F. (2016). Proyek buku digital: Upaya peningkatan keterampilan Abad 21 calon guru sekolah dasar melalui model pembelajaran berbasis proyek. Metodik Didaktik, 9(2), 1-15. https://doi.org/10.17509/md.v9i2.3248

Ding, L., Reay, N., Lee, A., \& Bao, L. (2011). Exploring the role of conceptual scaffolding in solving synthesis problems. Physical Review Special Topics - Physics Education Research, 7(2), 020109. https://doi.org/10.1103/PhysRevSTPER.7.020109

Endarko, E., Muntini, M. S., Prasetio, L., \& Faisal, H. (2008). Fisika untuk SMK teknologi (D. Darminto 
(ed.)). Direktorat Pembinaan Sekolah Menengah Kejuruan, Direktorat Jenderal Manajemen Pendidikan Dasar dan Menengah, Departemen Pendidikan Nasional.

Evers, J. C., \& Silver, C. (2014). Conference report: The first ATLAS.ti user conference. Forum Qualitative Sozialforschung / Forum: Qualitative Social Research, 15(1). https://doi.org/10.17169/fqs-15.1.2096

Fajriatin, A. (2015). Analisis buku siswa matematika Kurikulum 2013 kelas IX bab sistem persamaan linear dua variabel berdasarkan konten pada kriteria Bell. Seminar Nasional Matematika Dan Pendidikan Matematika UNY 2015, 71-76.

Fatima, G., Shah, S. K., \& Sultan, H. (2015). Textbook analysis and evaluation of 7th \& 8th Grade in Pakistani context. International Journal of English Language Teaching, 3(4), 79-97. http://www.eajournals.org/wp-content/uploads/Textbook-Analysis-and-Evaluation-of-7th-8thGrade-in-Pakistani-Context.pdf

Fitriyah, M. (2017). Analisis konten buku teks pelajaran fisika kelas XI Kurikulum 2013 pada pokok 2017. Universitas Negeri Semarang.

Graneheim, U. ., \& Lundman, B. (2004). Qualitative content analysis in nursing research: concepts, procedures and measures to achieve trustworthiness. Nurse Education Today, 24(2), 105-112. https://doi.org/10.1016/j.nedt.2003.10.001

Hartono, H., Millati, I. I., \& Susanto, H. (2013). Analisis buku pelajaran fisika SMA kelas XI yang digunakan di Salatiga. Unnes Physic Education Journal, 2(2). https://doi.org/10.15294/upej.v2i2.2672

Hayat, B., \& Yusuf, S. (2010). Mutu pendidikan. Bumi Aksara.

Karim, S., Saepuzaman, D., \& Sriyansyah, S. P. (2016). The learning reconstruction of particle system and linear momentum conservation in introductory physics course. Journal of Physics: Conference Series, 739, 012111. https://doi.org/10.1088/1742-6596/739/1/012111

Kurnia, F., Zulherman, Z., \& Fathurohman, A. (2014). Analisis bahan ajar fisika SMA kelas XI di Kecamatan Indralaya Utara berdasarkan kategori literasi sains. Jurnal Inovasi Dan Pembelajaran Fisika, 1(1), 43-47. https://doi.org/10.36706/jipf.v1i1.1263

Kurniasih, I., \& Sani, B. (2014). Panduan membuat bahan ajar buku teks pelajaran sesuai dengan Kurikulum 2013 (1st ed.). Kata Pena.

Kusuma, D. (2018). Analisis keterbacaan buku teks fisika SMK kelas X. Jurnal Pendidikan Fisika Dan Sains (JPFS), 1(1), 14-21. http://journal.unucirebon.ac.id/index.php/jpfs/article/view/7

Levrini, O., Fantini, P., Pecori, B., \& Tasquier, G. (2014). Forms of productive complexity as criteria for educational reconstruction: The design of a teaching proposal on thermodynamics. Procedia Social and Behavioral Sciences, 116, 1483-1490. https://doi.org/10.1016/j.sbspro.2014.01.421

Lisdianto, D., Masykuri, M., \& Aminah, N. S. (2015). Pengembangan Integrated Contextual Module (ICM) untuk meningkatkan kreativitas dan kemampuan berpikir kritis siswa SMK pada pokok bahasan sifat mekanik bahan (Pembelajaran fisika di SMK Veteran 1 Sukoharjo tahun ajaran 2014/2015). INKUIRI: Jurnal Pendidikan IPA, 4(4), 2252-7893. https://doi.org/10.20961/inkuiri.v4i4.9646

Menteri Pendidikan dan Kebudayaan Republik Indonesia. (2018). Peraturan Menteri Pendidikan dan Kebudayaan Republik Indonesia Nomor 6 Tahun 2018 tentang Penugasan Guru Sebagai Kepala Sekolah. Kementerian Pendidikan dan Kebudayaan Republik Indonesia.

Menteri Pendidikan Nasional Republik Indonesia. (2008). Peraturan Menteri Pendidikan Nasional Republik Indonesia Nomor2 Tahun 2008 tentang buku. Kementerian Pendidikan Nasional Republik Indonesia.

Mulyanti, B., Purnama, W., \& Pawinanto, R. E. (2020). Distance learning in vocational high schools during the covid-19 pandemic in West Java province, Indonesia. Indonesian Journal of Science and Technology, 5(2), 271-282. https://doi.org/10.17509/ijost.v5i2.24640 
Niswa, A., \& Yulianto, B. (2013). Pengembangan bahan ajar mendengarkan berbasis video interaktif bermedia flash kelas VIID SMP Negeri 1 Kedamean. Jurnal Bahasa Dan Sastra Indonesia, 1(1). http://journal.unucirebon.ac.id/index.php/jpfs/article/view/7

O'Donoghue, G., Doody, C., \& Cusack, T. (2011). Physical activity and exercise promotion and prescription in undergraduate physiotherapy education: Content analysis of Irish curricula. Physiotherapy, 97(2), 145-153. https://doi.org/10.1016/j.physio.2010.06.006

Pasaribu, A., \& Saparini, S. (2017). Pengembangan bahan ajar berbasis kontekstual untuk meremidiasi miskonsepsi pada materi gaya dan hukum Newton tentang gerak. Jurnal Inovasi Dan Pembelajaran Fisika, 4(1), 36-47. https://doi.org/10.36706/jipf.v4i1.4264

Presiden Republik Indonesia. (2016). Instruksi Presiden Nomer 9 Tahun 2016 tentang revitalisasi Sekolah Menengah Kejuruan (SMK) dalam rangka peningkatan kualitas dan daya saing sumber daya manusia (SDM) Indonesia. Sekertariat Kabinet Republik Indonesia.

Saepuzaman, D., \& Karim, S. (2016). Desain pembelajaran student's conceptual construction guider berdasarkan kesulitan mahasiswa calon guru fisika pada konsep gerak parabola. Jurnal Penelitian \& Pengembangan Pendidikan Fisika, 2(2), 79-86. https://doi.org/10.21009/1.02211

Sekarwinahyu, M., \& Rahayu, U. (2009). Kajian terhadap kualitas bahan ajar non cetak program s1 pendidikan biologi dalam pembelajaran interaktif spjj. Jurnal Pendidikan Terbuka Dan Jarak Jauh, 10(1), 38-50. http://jurnal.ut.ac.id/index.php/jptjj/article/view/472

Seung, E., Bryan, L. A., \& Haugan, M. P. (2012). Examining physics graduate teaching assistants' pedagogical content knowledge for teaching a new physics curriculum. Journal of Science Teacher Education, 23(5), 451-479. https://doi.org/10.1007/s10972-012-9279-y

Sorge, S., Kröger, J., Petersen, S., \& Neumann, K. (2019). Structure and development of pre-service physics teachers' professional knowledge. International Journal of Science Education, 41(7), 862-889. https://doi.org/10.1080/09500693.2017.1346326

Taasoobshirazi, G., \& Farley, J. (2013). Construct validation of the physics metacognition inventory. International Journal of Science Education, 35(3), 447-459. https://doi.org/10.1080/09500693.2012.750433

Waloyo, E., \& Arrasyid, F. I. (2019). Pertimbangan guru dalam memilih buku paket siswa di MTsN I dan MAN I Kota Cirebon. http://repository.syekhnurjati.ac.id/3156/

Wilsa, A. W. (2019). Perbedaan hasil belajar siswa yang menggunakan multimedia interaktif dengan buku teks dalam pembelajaran biologi di SMA. Mangifera Edu, 4(1), 62-70. https://doi.org/10.31943/mangiferaedu.v4i1.42 